\title{
INDUCTION OF CADMIUM STRESS TOLERANCE IN TRITICUM AESTIVUM L. BY ALFALFA LEAF EXTRACT
}

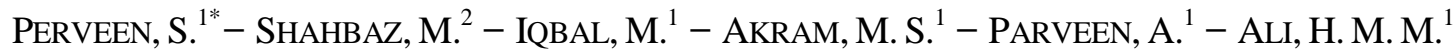 \\ ${ }^{1}$ Department of Botany, Government College University, Faisalabad, Pakistan \\ ${ }^{2}$ Department of Botany, University of Agriculture, Faisalabad, Pakistan \\ *Corresponding author \\ e-mail: perveens1@yahoo.com \\ (Received 27 $7^{\text {th }}$ Apr 2016; accepted 22 $2^{\text {nd }}$ Jul 2016)
}

\begin{abstract}
To assess the effect of foliar applications of alfalfa (Medicago sativa L.) leaf extract on three wheat (Triticum aestivum L.) varieties (Punjab-2011, Millat-2011 and Galaxy-2013) under cadmium (Cd) stress, two-week-old wheat plants were subjected to three levels of Cd (i.e. 0, 0.5 and $1.0 \mathrm{mM}$ ) stress and then foliarly applied with alfalfa leaf extract $(0$ and $2 \% \mathrm{w} / \mathrm{v})$. Data for 16-week-old wheat plants were collected for growth and physiochemical parameters, while yield were obtained at maturity. Cadmium stress significantly decreased growth, chlorophyll (chl.) $a$, flavonoids, total free amino acids, total soluble sugars and relative water contents (RWC \%), while increased chl. $b$, relative membrane permeability (RMP \%), malondialdehyde (MDA), total phenolics and free proline contents. Foliar treatment with alfalfa leaf extract $(2 \%)$ significantly increased growth, yield, leaf ascorbic acid, free proline and total soluble sugars, while decreased RMP (\%) (in Punjab-2011 and Galaxy-2013), flavonoids and $\mathrm{H}_{2} \mathrm{O}_{2}$ contents in all wheat varieties under cadmium stress. Wheat varieties showed significant difference as var. Punjab-2011 excelled in all measured attributes except RMP (\%), MDA and activity of POD, however, negative effect of cadmium stress was more prominent in var. Punjab-2011 than Millat-2011 and Galaxy-2013.
\end{abstract}

Keywords: chlorophyll, allelopathy, antioxidants, proline, ascorbic acid

\section{Introduction}

Metals with densities greater than $5 \mathrm{~g} \mathrm{~cm}^{-3}$ are known as heavy metals. Cadmium $(\mathrm{Cd})$ is one of the toxic heavy metals that decrease growth and development of plants due to its high mobility in phloem tissues and creates agricultural problems throughout the world (Page and Feller, 2015). Global estimated annual release of $\mathrm{Cd}$ is about 22,000 metric ton mainly through anthropogenic activities (Sing et al., 2003). Cadmium is highly soluble in water that can be easily taken up by plant roots and transported to upper parts of plant organs (Benavides et al., 2005; Amirjani, 2012). Metals transport from root to shoot through xylem driven by transpiration (Salt et al., 1995). Heavy metal transporters include legends such as phytochelatins, antioxidants, proline, heat shock proteins, polyamines, metallothioneins, nitric oxide and salicylic acid (Sunitha et al., 2012). Cadmium causes several physiological disorders and promotes inhibition of metabolism (Elobeid et al., 2012). Cadmium has negative effects on photosynthetic pigments (Parmer et al., 2013), electron transport chain in photosynthesis, and alter membrane structure due to phospholipids degradation in cell membrane (Dhir et al., 2004). Metals accumulate in different plant species such as mustard (Brassica campestris L.) (Khan et al., 2016), sunflower (Helianthus annuus L.) (Iqbal et al., 2015; Abd-Allah et al., 2015), soybean (Glycine max L.) (Abdo et al., 2012), cucumber (Cucumis sativus L.) (Sun et al., 2015) and exert health hazard effects on animals by entering in the food chain (Khan et al., 2016). 
For achieving high-quality products some appropriate and improved practices are required to reduce time, labor, investment and availability of resources. There is a need to devise strategies for new genotypes of plants with high metal accumulation and toxicity tolerance (Iqbal et al., 2015). Exogenous application of plant growth regulators (PGRs) can increase growth rate and yield of crops under both control and stress conditions (Perveen et al., 2016). However, these PGRs are sometimes very costly and most of the time not available for the farmers in different regions of the country and globally. Some alternative low cost and eco-friendly strategy is of the need that could be cost-effective and easy to apply for the farmers. Crops are known to extract heavy metals from soil and hyper accumulator. It is known to bioaccumulate metals and could be used in phytoremidiation to phytoextract heavy metals $(\mathrm{Cd}$ and $\mathrm{Pb}$ ) in metal contaminated soils (Zhi-xin et al., 2007).

Alfalfa (Medicago sativa L.), a member of family Leguminosae (also Fabaceae) is an herbaceous, long-lived perennial legume (Ferreira et al., 2012). Alfalfa is used in rotation with other crops especially with the cereals crops to replenish the soil organic nitrogen reserves. Alfalfa has been reported to involve in uptake of about 40-50\% heavy metals (Cd and Zn) from sludge contaminated soil (Miller et al., 1995). A species of alfalfa (Medicago scutellata) has been reported to accumulate more $\mathrm{Cd}$ in shoot than in roots and could be used in phytoremidiation of contaminated soils (Darvishi and Kamajian, 2014). Ries et al. (1977) has reported a plant growth regulator, triacontanol (TRIA) in alfalfa (Medicago sativa L.). Later on, TRIA has been found to be very effective in increasing dry weight, leaf area per plant, level of reducing sugar, total amino acids and soluble proteins (Rice, 1985). Alfalfa leaf extract is more effective on crop plants than that of the stem and root extract (Randhawa et al., 2002; Asgharipour and Armin, 2010). Leaves and stems of alfalfa contain different concentrations of crude proteins, fibres as well as profile of amino acid at different growth stages (Popovic et al., 2001; Mauries, 2003). Alfalfa can affect the seed germination of plants due to the ammonia and saponins which is released from alfalfa residue (Miller, 1983). For example, alfalfa plant extract of different plant parts such as root, stem and leaf at 10, 20 and $50 \mathrm{~g} / \mathrm{l}$ has reduced the growth and germination rate of wheat plants (Mousavi et al., 2013). Alfalfa contains soluble chemicals that cause autotoxicity (Miller, 1996).

Wheat (Triticum aestivum L.) is a major cereal food crop for the people of Pakistan. Cadmium toxicity has been reported to reduce wheat growth and yield by causing adverse effects on physiological and biochemical attributes (Rady and Hemida, 2015). Exogenous application of organic fertilizers and use of allelopathic extract from crops as organic source is a promising approach for enhancing crop yield in agriculture sector (Oves et al., 2016). These plant-based biostimulants are thought to enhance plant growth, yield via improving the efficiency of plant metabolism, increasing tolerance to abiotic stresses, enhancing quality attributes of crops and facilitating uptake, translocation and assimilation of nutrients etc. (Ertani et al., 2014; Nardi et al., 2016). To examine the potential role of alfalfa leaf extract, it was hypothesized that foliar application of alfalfa leaf extract can reduce the adverse effects of cadmium stress on different growth and physiochemical attributes of different wheat varieties.

\section{Materials and Methods}

To explore the effect of alfalfa (Medicago sativa L.) leaf extract $(2 \%)$ on wheat (Triticum aestivum L.) under varying levels of cadmium $(\mathrm{Cd})(0,0.5$ and $1.0 \mathrm{mM})$ 
stress, seeds of three wheat varieties (Punjab-2011, Millat-2011 and Galaxy-2013) were obtained from Ayub Agricultural Research Institute (AARI) Faisalabad-Pakistan. Experiment was conducted during the years of 2014-2015 at Govt. College University, Faisalabad under natural climatic conditions. Ten seeds of each wheat variety were sown in plastic pots (12" long and $10^{\prime \prime}$ wide) containing thoroughly washed sand. There were total 72 pots and each variety contains 24 pots (6 treatments with 4 replicates). Two-week-old wheat plants were subjected to three levels of cadmium $(0,0.5$ and 1.0 $\mathrm{mM}$ ) stress. Fresh alfalfa leaf samples were collected from AARI, Faisalabad and air dried at room temperature. To $10 \mathrm{~g}$ crushed leaves added $100 \mathrm{ml}$ of distilled water and kept at room temperature for 48 hours, filtered this mixture with Whitman's filter paper. The filtrate was diluted to various levels by applying molality formula. Two levels [0 and $2 \%$ (optimized out of $0,2,4,6,8$ and $10 \mathrm{v} / \mathrm{v}$ )] of alfalfa leaf extract were foliarly sprayed at the rate of $25 \mathrm{ml}$ per pot to 4-week-old wheat plants. Data of 16week-old wheat plants (nourished with full strength Hoagland's, nutrient solution) were collected for the determination of various parameters. Two plants from each pot were uprooted with proper care to avoid any root damage and measured fresh and dry biomass, lengths of shoot and root and total leaf area per plant. Then the same plant samples were air dried for two weeks, kept in an oven at $65^{\circ} \mathrm{C}$ for 48 hours and determined shoot and root dry weights, while yield attributes were determined at maturity.

\section{Determination of relative water contents $(R W C \%)$}

Fresh leaf samples were collected and determined their fresh weight (FW) with analytical balance. Then leaf samples were kept overnight in $10 \mathrm{ml}$ distilled water and determined turgid weight (TW); oven-dried at $65^{\circ} \mathrm{C}$ for 48 hours and determined dry weight (DW) according to Jones and Turner (1978) method.

\section{Percentage relative membrane permeability (RMP \%)}

Fresh leaf $(0.5 \mathrm{~g})$ were chopped and added $10 \mathrm{ml}$ distilled water in test tubes and calculated electrical conductivity $\left(\mathrm{EC}_{\mathrm{o}}\right)$, vortexed and determined $\mathrm{EC}_{1}$ and then autoclaved the samples for $1 \mathrm{~h}$ at $90^{\circ} \mathrm{C}$, cooled at room temperature and calculated $\mathrm{EC}_{2}$. Membrane permeability (\%) was calculated by using the following formulae $\mathrm{RMP}(\%)=\mathrm{EC}_{1}-\mathrm{EC}_{\mathrm{o}} / \mathrm{EC}_{2}-\mathrm{EC}_{\mathrm{o}} \times 100$.

\section{Determination of chlorophyll contents}

Fresh leaf $(0.5 \mathrm{~g})$ were extracted in $10 \mathrm{ml}$ of $80 \%$ acetone and kept at $4^{\circ} \mathrm{C}$ in refrigerator. Chlorophyll contents were determined at the wavelengths 663 and $645 \mathrm{~nm}$ on spectrophotometer (Hitachi-U-1800, Japan) according to the method of Arnon (1949).

\section{Determination of hydrogen peroxide $\left(\mathrm{H}_{2} \mathrm{O}_{2}\right)$ contents}

Velikova et al. (2000) protocol was used for $\mathrm{H}_{2} \mathrm{O}_{2}$ contents determination. Fresh leaf $(0.5 \mathrm{~g})$ samples were finely homogenized in $10 \mathrm{ml}$ of $0.1 \%(\mathrm{w} / \mathrm{v})$ trichloroacetic acid (TCA) in an ice both. The samples were centrifuged at $12,000 \times \mathrm{g}$ for $15 \mathrm{~min}$. at $4^{\circ} \mathrm{C}$. To $0.5 \mathrm{ml}$ supernatant solution, added $0.5 \mathrm{ml}$ of potassium buffer $(50 \mathrm{mM} ; \mathrm{pH}=7)$ and 1 $\mathrm{ml}$ of potassium iodide (KI) solution. Absorbance of supernatant was determined with 
spectrophotometer at $390 \mathrm{~nm}$ wavelength. The values for $\mathrm{H}_{2} \mathrm{O}_{2}$ were computed by using the standard calibration curve values at different concentrations of $\mathrm{H}_{2} \mathrm{O}_{2}$

\section{Determination of malondialdehyde (MDA) contents}

Carmak and Horst (1991) method was used for MDA determination. Fresh leaf $(0.5$ g) finely ground in $10 \mathrm{ml}$ of $0.1 \%$ trichloroacetic acid (TCA) andcentrifuged at 12,000 $\times g$ for $15 \mathrm{~min}$. at $4^{\circ} \mathrm{C}$. To $1 \mathrm{ml}$ of supernatant added $0.5 \%$ of $4 \mathrm{ml}$ thiobarbituric acid (TBA) (prepared in $20 \%$ TCA) and heated that mixture at $95^{\circ} \mathrm{C}$ for $25 \mathrm{~min}$ in a water bath. The samples were cooled in an ice bath and centrifuged at 7,500 $\times \mathrm{g}$ for $5 \mathrm{~min}$. and read the absorbance at two wave lengths 532 and $600 \mathrm{~nm}$ on spectrophotometer.

\section{Determination of total phenolics}

Total phenolic contents were determined by using the method of Julkenen-Titto (1985) method. Fresh leaf $(0.1 \mathrm{~g})$ was ground in $2 \mathrm{ml}$ of $80 \%$ acetone andcentrifuged at $15,000 \times \mathrm{g}$ for $15 \mathrm{~min}$. at $4^{\circ} \mathrm{C}$. To $0.1 \mathrm{ml}$ of supernatant, added $2 \mathrm{ml}$ of distilled $\mathrm{H}_{2} \mathrm{O}$ and $0.5 \mathrm{ml}$ Folin-Ciocalteau's phenol reagent (FC- reagent) and shake. Then $2.5 \mathrm{ml}$ of sodium carbonate (20\%) was added to above mixture and made final volume up to $5 \mathrm{ml}$, vortexed for $5 \mathrm{~s}$ and incubated the sample at room temperature $\left(20^{\circ} \mathrm{C}\right)$ for 15 minutes. The absorbance of prepared sample mixture was determined by using spectrophotometer at $750 \mathrm{~nm}$.

\section{Determination of ascorbic acid contents}

Mukherjee and Choudhuri (1983) method was used for ascorbic acid contents determination. Fresh leaf $(0.25 \mathrm{~g})$ was finely homogenized in $10 \mathrm{ml}$ of $6 \%$ TCA. Two 2 $\mathrm{ml}$ dinitrophenyl hydrazine $(2 \%)$ was added in $2 \mathrm{ml}$ of supernatant and one drop of 10 $\%$ thiourea and reaction mixture heated in a water bath for $20 \mathrm{~min}$. After cooling $5 \mathrm{ml}$ $\mathrm{H}_{2} \mathrm{SO}_{4}(80 \%)$ was added in a test tube and absorbance was taken at $520 \mathrm{~nm}$ with the help of spectrophotometer.

\section{Determination of total free amino acid}

Moore and Stein (1957) method was used for the determination of free amino acids. Fresh leaf $(0.5 \mathrm{~g})$ was homogenized in $10 \mathrm{ml}$ of citrate buffer $(\mathrm{pH} \mathrm{5.0)}$. Then supernatant was centrifuged at $15,000 \times \mathrm{g}$ for $10 \mathrm{~min}$. One $\mathrm{ml}$ of extract was added in 1 $\mathrm{ml}$ of $10 \%$ pyridine solution and $1 \%$ ninhydrin solution in test tubes. Then heat the solution at $95^{\circ} \mathrm{C}$ for $30 \mathrm{~min}$. and read the optical density of the prepared solution at 570 nm by using spectrophotometer.

\section{Determination of free proline contents}

The method of Bates et al. (1973) was used for the determination of free proline contents. Fresh leaf $(0.5 \mathrm{~g})$ was homogenized in $10 \mathrm{ml}$ of $3 \%$ aqueous sulfosalicylic acid solution and filtered. To $2 \mathrm{ml}$ of filtrate added $2 \mathrm{ml}$ each of glacial acetic acid and acid ninhydrine in test tubes. Then the mixture was heated in water bath at $95^{\circ} \mathrm{C}$, cooled in an ice bath. To reaction mixture added $4 \mathrm{ml}$ of toluene and vortexed for 10-15 s. The optical density of mixture was obtained at $520 \mathrm{~nm}$ using spectrophotometer. 


\section{Determination of total soluble sugars}

Fresh leaf tissue $(0.1 \mathrm{~g})$ was ground in $5 \mathrm{ml}$ of $0.2 \%$ phosphate buffer. To $0.1 \mathrm{ml}$ of supernatant added $3 \mathrm{ml}$ of freshly prepared anthrone reagent, shake it well and heated in a water bath at a $95^{\circ} \mathrm{C}$ for $15 \mathrm{~min}$. The absorbance was measured after cooling at 625 $\mathrm{nm}$ using spectrophotometer.

\section{Determination of flavonoides}

Flavonoides were determined according to the method of Zhishen et al. (1999). Fresh leaf $(0.1 \mathrm{~g})$ was extracted in acetone $(80 \%)$. To $0.5 \mathrm{ml}$ of supernatant added $2 \mathrm{ml}$ of distilled water, $0.6 \mathrm{ml}$ of $\mathrm{NaNO}_{2}(5 \%), 0.5 \mathrm{ml}$ of $\mathrm{AlCl}_{3}(10 \%)$ and $2 \mathrm{ml}$ of $\mathrm{NaOH}(1 \mathrm{M})$ and reading of mixture was recorded at $510 \mathrm{~nm}$ with a spectrophotometer.

\section{Statistical analysis of experiment}

Analysis of variance (ANOVA) of data for completely randomized design was performed via Co-STAT computer program to compare least significant difference using method of Snedecor and Cochran (1980).

\section{Results}

Cadmium stress of varying levels $(0.0,0.5$ and $1.0 \mathrm{mM})$ significantly $(P \leq 0.001)$ decreased shoot fresh and dry weights of all wheat varieties (Fig. 1a, b). Foliar application of alfalfa leaf extract at the rate of $2 \%(\mathrm{v} / \mathrm{v})$ significantly increased shoot fresh $(P \leq 0.05)$ and dry $(P \leq 0.001)$ weights in all three wheat varieties under both nonstress and $\mathrm{Cd}$ stress conditions. All wheat varieties exhibited significant $(P \leq 0.001)$ difference under cadmium stress (Table 1). Galaxy-2013 showed more tolerance to cadmium stress as compared to Punjab-2011 and Millat-2011. For example, under 1.0 $\mathrm{mM}$ Cd Punjab-2011 showed more reduction in shoot fresh and dry weights (65.37, $57.53 \%$ and $71.73,58.17 \%)$ as compared to Millat-2011 (57.43, 45.52\% and 52.88, $40.25 \%)$ and Galaxy-2013 (39.58, 1.05\% and 41.07, 1.30\%) under non-spray or alfalfa spray conditions respectively.

Root fresh and dry weights significantly $(P \leq 0.001)$ decreased in all three wheat varieties (Punjab-2011, Millat-2011 and Galaxy-13) (Fig. 1c, d). Varieties showed significant $((P \leq 0.001)$ difference under cadmium stress as varieties Galaxy-2013 and Punjab-2011 showed more reduction in root fresh and dry weight as compared to Millat-2011 (Table 1). Foliar application of alfalfa leaf extract (2\%) significantly increased root fresh $(P \leq 0.05)$ and dry $(P \leq 0.01)$ weights in Punjab-2011 under Cdstressed or non-stressed conditions, while in Millat-2011 under Cd-stress conditions. Galaxy-2013 showed variable response in root fresh weight, while increased root dry weight under both $\mathrm{Cd}$-stress regimes.

Cadmium stress significantly $(P \leq 0.001)$ decreased root and shoot lengths in all wheat varieties (Fig. 1e, $f$ ). Foliar application of alfalfa leaf extract significantly $(P \leq 0.001)$ increased shoot length in all wheat varieties (Table 1 ). All varieties showed significant $(P \leq 0.01)$ difference under cadmium stress as Punjab-2011 showed more reduction in shoot $(34.32,29.55 \%)$ lengths as compared to Millat-2011 $(21.29,25.79 \%)$ and Galaxy$2013(6.25,15.65 \%)$ under non-spray and foliar application of alfalfa aqueous extract respectively. Galaxy-2013 showed more tolerance to cadmium stress and increased growth by foliar application of alfalfa leaf extract (Table 1). Furthermore, root length 
significantly $(P \leq 0.01)$ decreased in Punjab-2011 and Millat-2011, while Galaxy-2013 showed uniform behavior under Cd-stress. All wheat varieties showed variable response in terms of root length. For example, root length decreased in Millat-2011 under Cdstress or non-stress conditions, while increased in Punjab-2011 and Galaxy-2013 by foliar application of alfalfa leaf extract under $0.5 \mathrm{mM}$ and $1.0 \mathrm{mM} \mathrm{Cd}$ levels respectively (Table 1).

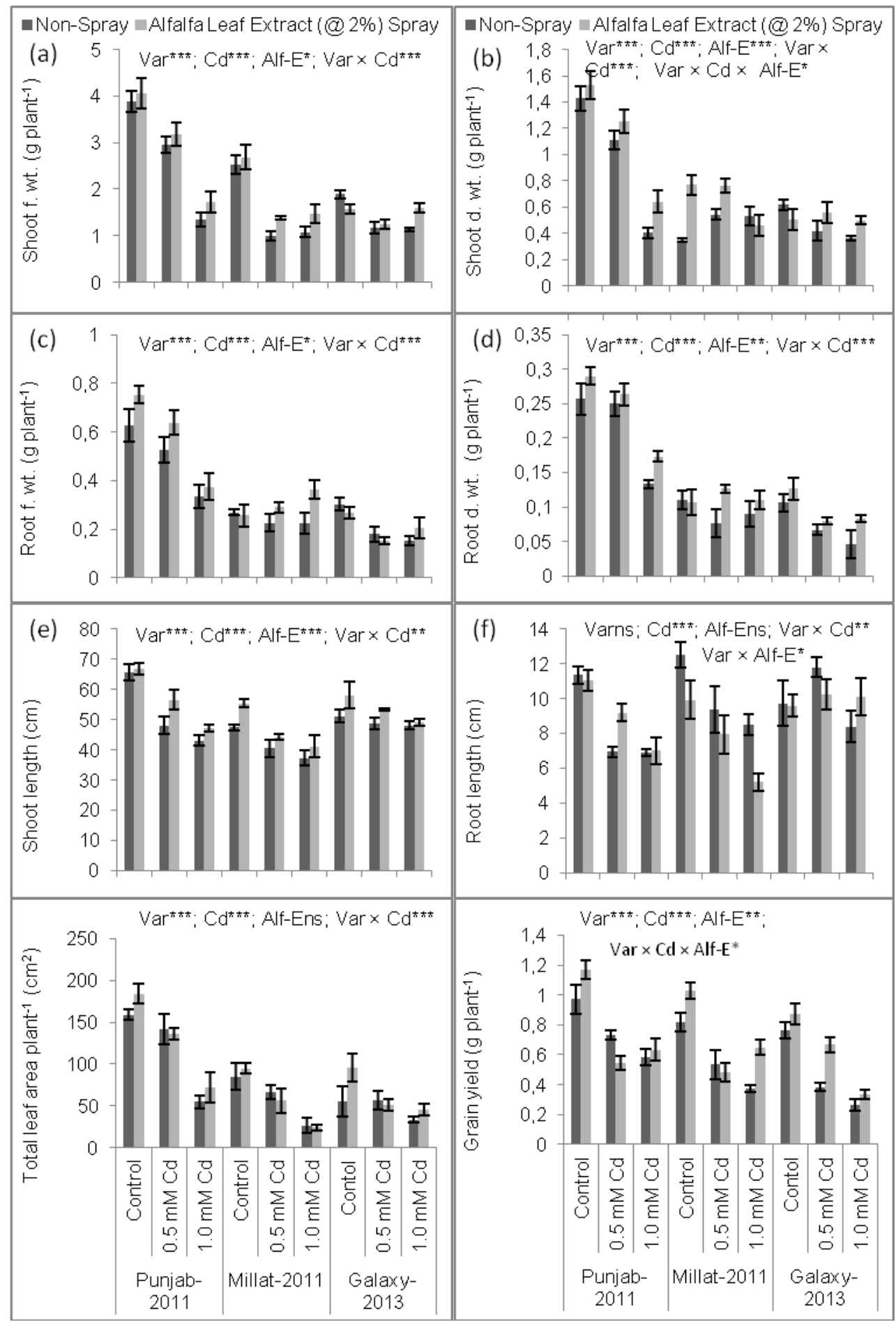

Figure 1. Growth and yield parameters of 16-week-old wheat plants foliarly sprayed with $2 \%$ alfalfa leaf extract under cadmium stress and non-stress conditions. 
Total leaf area per plant significantly $(P \leq 0.001)$ decreased under varying levels of cadmium stress in all three wheat varieties (Fig. $1 \mathrm{~g}$ ). Foliar application of alfalfa leaf extract did not alter leaf area per plant under Cd stress or non-stress conditions. All three wheat varieties showed significant difference as Punjabb-2011 was higher in total leaf area per plant as compared to Millat-2011 and Galaxy-2013. However, cadmiuminduced reduction in leaf area was more prominent in Millat-2011 than that of Punjab2011 and Galaxy-2013 (Table 1).

Table 1. Analysis of variance of the data for various growth, yield, yield components, relative water content (\%) and membrane permeability of wheat plants foliarly-sprayed with $2 \%$ alfalfa leaf extract under cadmium stress and non-stress conditions.

\begin{tabular}{|c|c|c|c|c|c|}
\hline $\begin{array}{l}\text { Source of } \\
\text { Variations }\end{array}$ & $\mathrm{df}$ & Shoot f. wt. & Shoot dry wt. & Root f. wt. & Root dry wt. \\
\hline Variety (Var) & 2 & $10.37 * * *$ & $1.701 * * *$ & $0.558 * * *$ & $0.108 * * *$ \\
\hline Cadmium (Cd) & 2 & $8.995 * * *$ & $0.720 * * *$ & $0.085 * * *$ & $0.016 * * *$ \\
\hline $\begin{array}{l}\text { Alfalfa Extract } \\
\text { (Alf-E) }\end{array}$ & 1 & $0.614^{*}$ & $0.249 * * *$ & $0.035^{*}$ & $0.008 * *$ \\
\hline $\operatorname{Var} \times \mathrm{Cd}$ & 4 & $2.199 * * *$ & 0.390 & $0.059 * * *$ & 0.006 *** \\
\hline Var $\times$ Alf-E & 2 & $0.068 \mathrm{~ns}$ & $0.0233 \mathrm{~ns}$ & $0.0108 \mathrm{~ns}$ & $0.000 \mathrm{~ns}$ \\
\hline $\mathrm{Cd} \times$ Alf-E & 2 & $0.181 \mathrm{~ns}$ & $0.005 \mathrm{~ns}$ & $0.003 \mathrm{~ns}$ & $0.000 \mathrm{~ns}$ \\
\hline $\operatorname{Var} \times \mathrm{Cd} \times$ Alf-E & 4 & $0.040 \mathrm{~ns}$ & $0.062 *$ & $0.006 \mathrm{~ns}$ & $0.000 \mathrm{~ns}$ \\
\hline Error & 36 & 0.122 & 0.018 & 0.006 & 0.000 \\
\hline $\begin{array}{l}\text { Source of } \\
\text { Variations }\end{array}$ & $\mathrm{df}$ & $\begin{array}{l}\text { Shoot length } \\
(\mathrm{cm})\end{array}$ & $\begin{array}{l}\text { Root length } \\
\text { (cm) }\end{array}$ & $\begin{array}{l}\text { Total leaf } \\
\text { area plant }^{-1}\end{array}$ & $\begin{array}{l}\text { Grain yield ( } \mathrm{g} \\
\left.\text { plant }^{-1}\right)\end{array}$ \\
\hline Variety (Var) & & $492.5^{* * *}$ & $8.106 \mathrm{~ns}$ & $27163.2 * * *$ & $0.227 * * *$ \\
\hline Cadmium (Cd) & 2 & $810.9 * * *$ & $40.82 * * *$ & $22126.2 * * *$ & $1.098 * * *$ \\
\hline $\begin{array}{l}\text { Alfalfa Extract } \\
\text { (Alf-E) }\end{array}$ & 2 & $288.4 * * *$ & $4.564 \mathrm{~ns}$ & 1096.9ns & $0.151 * *$ \\
\hline Var $\times \mathrm{Cd}$ & 1 & $90.41 * *$ & $11.14 * *$ & $2351.9 * *$ & $0.023 \mathrm{~ns}$ \\
\hline Var $\times$ Alf-E & 4 & $1.22 \mathrm{~ns}$ & $11.95^{*}$ & $346.78 \mathrm{~ns}$ & $0.026 \mathrm{~ns}$ \\
\hline $\mathrm{Cd} \times$ Alf-E & 2 & $9.52 \mathrm{~ns}$ & $0.702 \mathrm{~ns}$ & $1180.01 \mathrm{~ns}$ & $0.030 \mathrm{~ns}$ \\
\hline Var $\times \mathrm{Cd} \times$ Alf-E & 2 & 16.10ns & $3.803 \mathrm{~ns}$ & $83.77 \mathrm{~ns}$ & $0.045^{*}$ \\
\hline Error & 4 & 21.29 & 2.695 & 540.7 & 0.013 \\
\hline $\begin{array}{l}\text { Source of } \\
\text { Variations }\end{array}$ & 36 & $\begin{array}{l}\text { Number of } \\
\text { grains plant } \\
{ }_{1}^{-}\end{array}$ & 100-grain wt. & RWC (\%) & RMP (\%) \\
\hline Variety (Var) & 2 & $301.85^{* * *}$ & $6.907 * *$ & $606.7 * * *$ & $211.71 * *$ \\
\hline Cadmium (Cd) & 2 & $435.3 * * *$ & $30.01 * * *$ & $294.7 * *$ & $288.53 * *$ \\
\hline $\begin{array}{l}\text { Alfalfa Extract } \\
\text { (Alf-E) }\end{array}$ & 1 & $20.16 \mathrm{~ns}$ & $0.000 \mathrm{~ns}$ & $8.14 \mathrm{~ns}$ & $3.697 \mathrm{~ns}$ \\
\hline Var $\times \mathrm{Cd}$ & 4 & $39.68 * * *$ & $3.435 *$ & $130.8 \mathrm{~ns}$ & $48.66 \mathrm{~ns}$ \\
\hline Var $\times$ Alf-E & 2 & $8.22 \mathrm{~ns}$ & $1.5 \mathrm{~ns}$ & $16.02 \mathrm{~ns}$ & $192.2^{* * *}$ \\
\hline $\mathrm{Cd} \times$ Alf-E & 2 & $7.166 \mathrm{~ns}$ & $0.5 \mathrm{~ns}$ & $19.65 \mathrm{~ns}$ & $40.09 \mathrm{~ns}$ \\
\hline Var $\times \mathrm{Cd} \times$ Alf-E & 4 & $14.38 \mathrm{~ns}$ & $0.416 \mathrm{~ns}$ & $49.86 n s$ & $35.14 \mathrm{~ns}$ \\
\hline Error & 36 & 6.129 & 0.962 & 53.98 & 35.58 \\
\hline
\end{tabular}

MP $(\%)=$ membrane permeability in percentage; RWC $(\%)=$ relative water content; $*, * *$, and $* * *=$ significant at $0.05,0.01$, and 0.001 levels, respectively; $\mathrm{df}=$ degrees of freedom; ns = non-significant. 
Yield and yield components significantly $(P \leq 0.001)$ decreased under various cadmium regimes (Fig. $1 \mathrm{~h}$ and Fig. 2a, b). Foliar application of alfalfa leaf extract significantly $(P \leq 0.01)$ increased grain yield per plant in all three wheat varieties. In terms of grain yield per plant var. Galaxy-2013 showed more positive response to foliar application of alfalfa-leaf extract under cadmium stress as compared to other varieties. Varieties also showed significant $(P \leq 0.001)$ difference under cadmium stress. For example, Punjab-2011 showed 57.60 and $56.31 \%$ reduction in number of grains/plant as compared to Millat-2011 (26.79, 33.33\%) and Galaxy-11 (60.02, 34.11\%). In hundred grain weight Punjab-2011 showed 48.01 and 38\% reduction as compared to Millat-2011 $(31.14,33.33 \%)$ and Galaxy-11 $(10.42,11 \%)$ respectively under cadmium stress and non-stress conditions (Table 1).

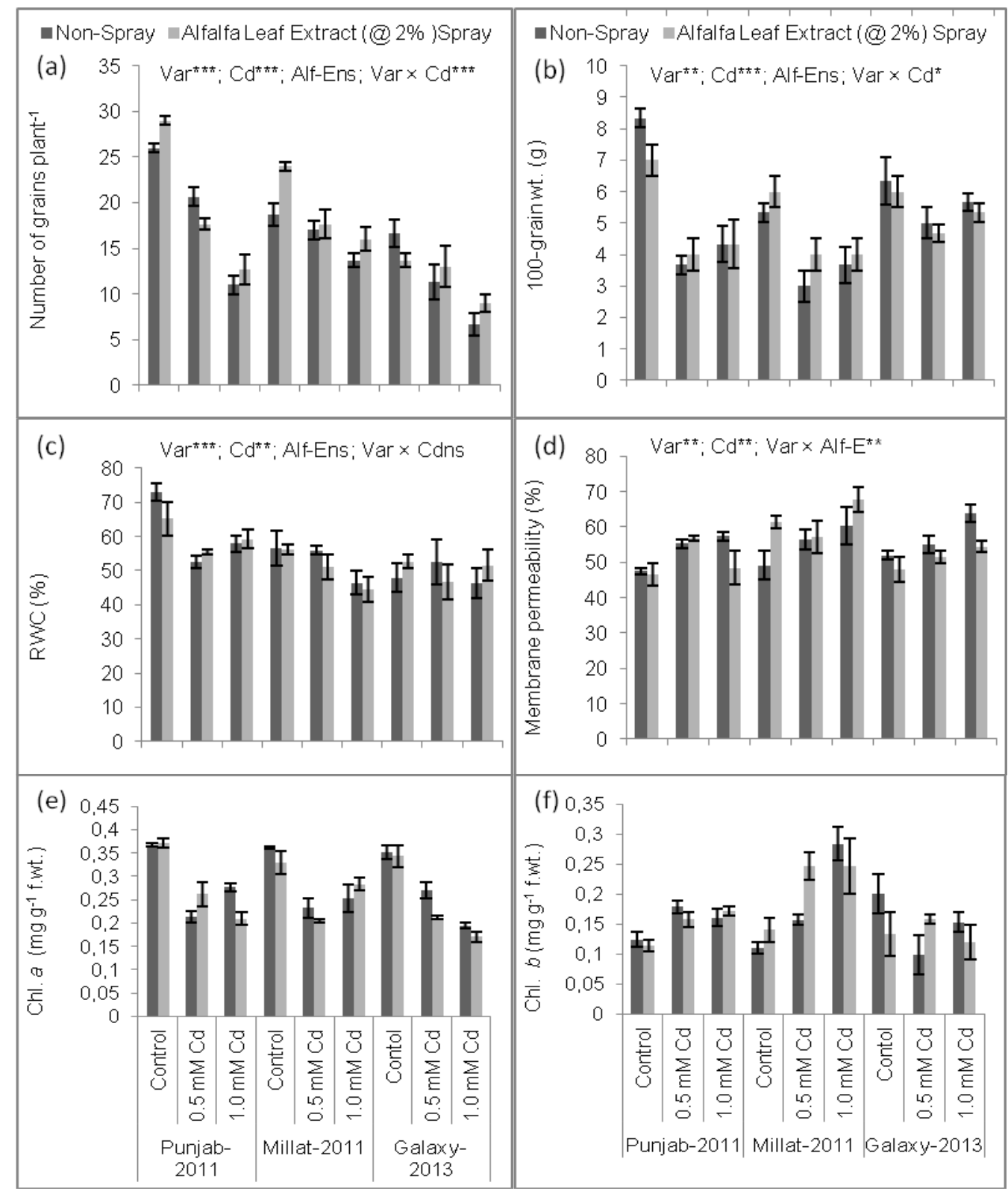

Figure 2. Yield parameters, relative water content (\%), membrane permeability (\%) and chlorophyll contents of 16-week-old wheat plants foliarly sprayed with $2 \%$ alfalfa leaf extract under cadmium stress and non-stress conditions. 
Relative water content $(\mathrm{RWC} \%)$ markedly $(P \leq 0.01)$ decreased in all wheat varieties under cadmium stress of varying levels (Fig. 2c). Reduction in RWC (\%) was more in Punjab-2011 and Millat-2011 that that of Galaxy-2013 (Table 1). Imposition of foliar treatment with alfalfa extract did not alter RWC (\%) significantly. Overall, under nonstress conditions wheat variety Punjab-2011 was higher in relative water content. However, under cadmium stress, reduction in relative water contents was more prominent in var. Punjab-2011 and var. Millat-2011 than that of var. Galaxy-2013.

Chlorophyll (chl.) ' $a$ ' contents significantly $(P \leq 0.001)$ decreased under cadmium stress in all wheat varieties. Varieties showed significant difference in chlorophyll contents (Fig. 2e,f). Overall, foliar treatment with alfalfa leaf extract did not modulate chlorophyll contents significantly under cadmium stress or non stress conditions (Table 2). However, under $0.1 \mathrm{mM}$ Cd-stress wheat var. Millat-2011 showed higher chl. ' $a$ contents than var. Punjab-2011 and var. Galaxy-2013 under both Cd-stress and by foliar application of alfalfa leaf extract. Similarly, under varying levels of Cd-stress var. Millat-2011 showed higher chl. ' $b$ ' contents as compared to var. Punjab-2011 and Galaxy-2013.

Cadmium stress caused significant $(P \leq 0.05)$ increase in $\mathrm{H}_{2} \mathrm{O}_{2}$ and MDA contents in all wheat varieties (Fig. $2 h, 3 a$ ). Foliar treatment with alfalfa leaf extract significantly $(P \leq 0.05)$ decreased $\mathrm{H}_{2} \mathrm{O}_{2}$ and MDA contents (Table 2). Of all wheat varieties, Galaxy2013 was high in $\mathrm{H}_{2} \mathrm{O}_{2}$ and MDA contents as compared to Punjab-2011 and Millat2011 (Fig. 2h, 3a).

Table 2. Analysis of variance of the data for photosynthetic pigments, hydrogen peroxide, malondialdehyde, total phenolics, ascorbic acid, total free amino acids, free proline, ascorbic acid, soluble sugars and flavonoid contents of wheat plants foliarly-sprayed with $2 \%$ alfalfa leaf extract under cadmium stress and non-stress conditions.

\begin{tabular}{llllll}
\hline $\begin{array}{l}\text { Source of } \\
\text { Variations }\end{array}$ & df & Chl. $a$ & Chl. $b$ & $\mathrm{H}_{2} \mathrm{O}_{2}$ & MDA \\
\hline Variety (Var) & 2 & $0.0034^{*}$ & $0.015^{* *}$ & $0.378^{* * *}$ & $9.938^{*}$ \\
\hline Cadmium $(\mathrm{Cd})$ & 2 & $0.090^{* * *}$ & $0.012^{* *}$ & $0.064 \mathrm{~ns}$ & $9.602^{*}$ \\
\hline $\begin{array}{l}\text { Alfalfa Extract } \\
(\text { Alf-E) }\end{array}$ & 1 & $0.003 \mathrm{~ns}$ & $0.000 \mathrm{~ns}$ & $0.102^{*}$ & $7.31 \mathrm{~ns}$ \\
\hline Var $\times$ Cd & 4 & $0.005^{* *}$ & $0.012^{* *}$ & $0.040 \mathrm{~ns}$ & $0.534 \mathrm{~ns}$ \\
\hline Var $\times$ Alf-E & 2 & $0.000 \mathrm{~ns}$ & $0.002 \mathrm{~ns}$ & $0.019 \mathrm{~ns}$ & $0.045 \mathrm{~ns}$ \\
\hline Cd $\times$ Alf-E & 2 & $0.000 \mathrm{~ns}$ & $0.005 \mathrm{~ns}$ & $0.082^{*}$ & $8.89^{*}$ \\
\hline Var $\times$ Cd $\times$ Alf-E & 4 & $0.004^{* *}$ & $0.004 \mathrm{~ns}$ & $0.006 \mathrm{~ns}$ & $0.157 \mathrm{~ns}$ \\
\hline Error & 36 & 0.001 & 0.002 & 0.023 & 2.12 \\
\hline $\begin{array}{l}\text { Source of } \\
\text { Variations }\end{array}$ & df & $\begin{array}{l}\text { Total } \\
\text { phenolics }\end{array}$ & $\begin{array}{l}\text { Ascorbic } \\
\text { acid }\end{array}$ & $\begin{array}{l}\text { Total free } \\
\text { amino acids }\end{array}$ & Free proline \\
\hline Variety $($ Var $)$ & 2 & $25.78 \mathrm{~ns}$ & $4.332^{* * *}$ & $7.660^{* *}$ & $575.88^{* * *}$ \\
\hline Cadmium $($ Cd $)$ & 2 & $37.62^{*}$ & $0.613 \mathrm{~ns}$ & $5.59^{* *}$ & $79.806^{*}$ \\
\hline $\begin{array}{l}\text { Alfalfa Extract } \\
(\text { Alf-E) }\end{array}$ & 1 & $0.921 \mathrm{~ns}$ & $1.841^{*}$ & $0.124 \mathrm{~ns}$ & $229.7 * *$ \\
\hline Var $\times$ Cd & 4 & $8.320 \mathrm{~ns}$ & $9.009^{* * *}$ & $2.198 \mathrm{~ns}$ & $35.64 \mathrm{~ns}$ \\
\hline Var $\times$ Alf-E & 2 & $1.632 \mathrm{~ns}$ & $0.993 \mathrm{~ns}$ & $0.359 \mathrm{~ns}$ & $6.761 \mathrm{~ns}$ \\
\hline Cd $\times$ Alf-E & 2 & $3.464 \mathrm{~ns}$ & $0.006 \mathrm{~ns}$ & $3.029 \mathrm{~ns}$ & $6.881 \mathrm{~ns}$ \\
\hline Var $\times$ Cd $\times$ Alf-E & 4 & $1.148 \mathrm{~ns}$ & $0.265 \mathrm{~ns}$ & $1.112 \mathrm{~ns}$ & $8.090 \mathrm{~ns}$ \\
\hline Error & 36 & 10.26 & 0.360 & 1.065 & 17.72 \\
\hline
\end{tabular}




\begin{tabular}{llll}
\hline $\begin{array}{l}\text { Source of } \\
\text { Variations }\end{array}$ & df & $\begin{array}{l}\text { Soluble } \\
\text { sugars }\end{array}$ & Flavonoids \\
\hline Variety (Var) & 2 & $2870.2^{* * *}$ & $4.470^{* * *}$ \\
\hline Cadmium $(\mathrm{Cd})$ & 2 & $1463.7^{* * *}$ & $3.389^{* * *}$ \\
\hline $\begin{array}{l}\text { Alfalfa Extract } \\
(\text { Alf-E) }\end{array}$ & 1 & $209.9^{*}$ & $1.243^{* * *}$ \\
\hline Var $\times$ Cd & 4 & $429.9^{* * *}$ & $0.662^{* * *}$ \\
\hline Var $\times$ Alf-E & 2 & $110.5^{*}$ & $0.239 \mathrm{~ns}$ \\
\hline Cd $\times$ Alf-E & 2 & $113.7^{*}$ & $0.159 \mathrm{~ns}$ \\
\hline Var $\times$ Cd $\times$ Alf-E & 4 & $126.9^{*}$ & $0.305^{*}$ \\
\hline Error & 36 & 33.8 & 0.085 \\
\hline
\end{tabular}

MDA = malondialdehyde; $\mathrm{H}_{2} \mathrm{O}_{2}=$ hydrogenperoxide; Chl. $a=$ chlorophyll $a$; Chl. $b=$ chlorophyll $b$; $\mathrm{df}=$ degrees of freedom; $\mathrm{ns}=$ non-significant; $*, * *$, and $* * *=$ significant at $0.05,0.01$, and 0.001 levels, respectively.

Cadmium stress of varying levels significantly $(P \leq 0.05)$ increased total phenolic (Fig. 3c) contents in all the three wheat varieties. Ascorbic acid contents increased in Punjab-2011 and Millat-2011, while decreased in Galaxy-2013 under cadmium stress (Fig. 3d). Foliar treatment with alfalfa extract did not alter total phenolics, while increased ascorbic acid contents in Punjab-2011 and Millat-2011 (Table 2). Accumulation of ascorbic acid contents was high in wheat var. Punjab-2011 and Millat-2011 than that of var. Galaxy-2013.

Cadmium stress of varying levels significantly $(P \leq 0.01)$ decreased total free amino acids, while increased $(P \leq 0.05)$ free proline in all wheat varieties $($ Fig. $3 e$, $f)$. Foliar application of alfalfa leaf extract did not change total free amino acids, while increased free proline contents in all varieties under cadmium stress or non stress conditions (Table 2). Varieties showed significant $(P \leq 0.01)$ difference as Galaxy-2013 was higher in total free amino acids contents as compared to Pujab11 and Millat-2011, while reverse was true in the case of free proline contents. Effect of $1.0 \mathrm{mM}$ cadmium was more intense as compared to $0.5 \mathrm{mM}$ on all the three wheat varieties.

Current study revealed that cadmium stress significantly $(P \leq 0.001)$ decreased total soluble sugars and flavonoid contents in all three wheat varieties (Fig. $3 g, h)$. Varieties showed significant $(P \leq 0.001)$ difference under $\mathrm{Cd}$ stress or non-stress conditions (Table 2). Overall, Punjab-2011 highly accumulated total soluble sugars and flavonoid contents than that of Millat-2011 and Galaxy-2013. Foliar application of alfalfa extract $(P \leq 0.05)$ increased total soluble sugars in Millat2011, while decreased in Galaxy-2013 under Cd stress conditions. However, flavonoid contents decreased by foliar treatment with $2 \%$ alfalfa leaf extract in all three wheat varieties under stressed or non-stressed conditions (Fig. $3 g, h$ ). Cadmium stress caused more reduction in both total soluble sugars and flavonoid contents in Galaxy-2013 as compared to other two wheat varieties. 


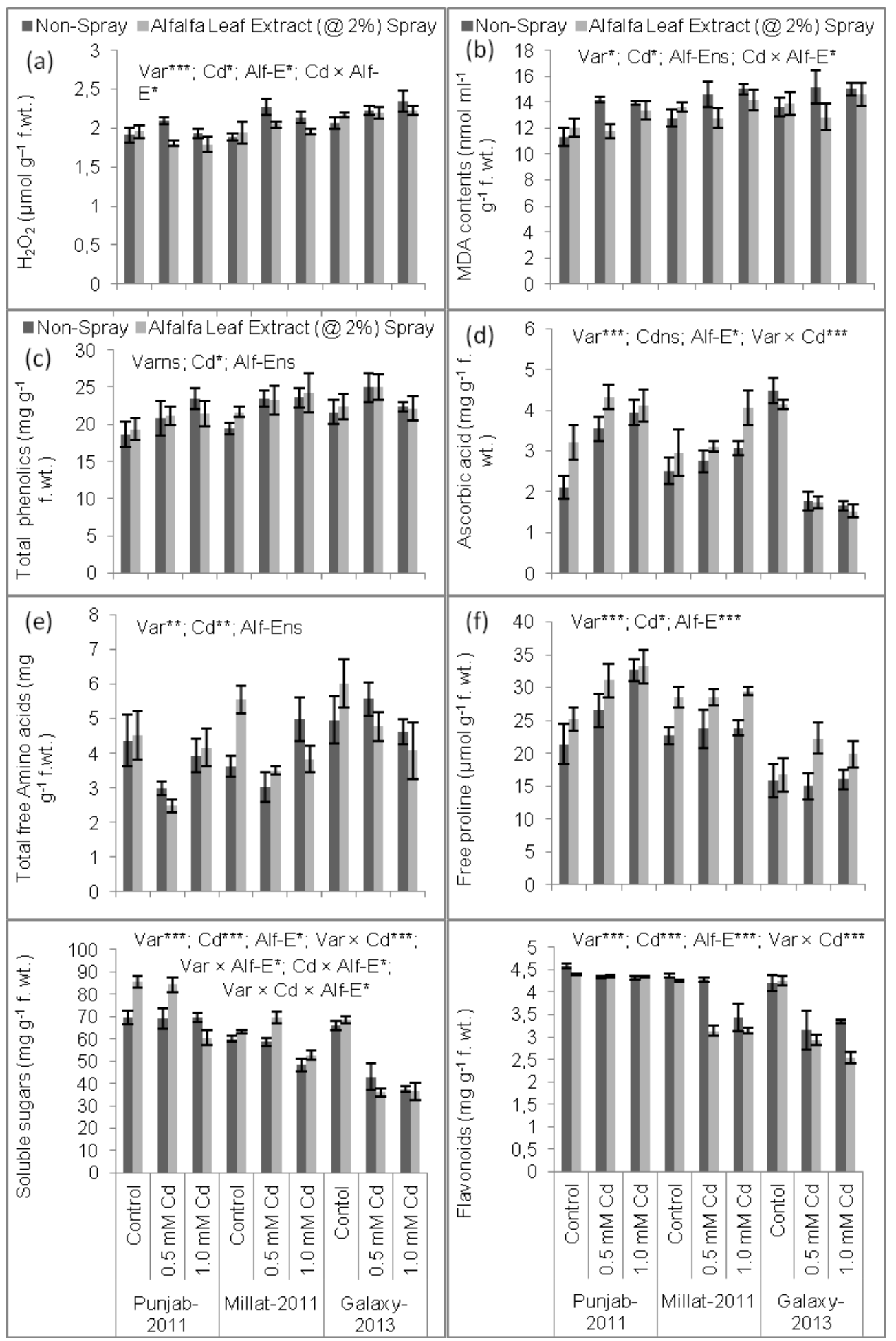

Figure 3. Hydrogen peroxide, malondialdehyde, total phenolic, ascorbic acid, amino acids, free proline, soluble sugars and flavonoids of 16-week-old wheat plants foliarly sprayed with $2 \%$ alfalfa leaf extract under cadmium stress and non-stress conditions. 


\section{Discussion}

Plants must have tolerance to heavy metal pollutants, ability to metabolize and immobilize metals and large biomass to remediate widespread chemicals in field. Plants tolerate to heavy metals through metal detoxification mechanism such as chelation of heavy metals with organic acids and high affinity ligands like metallothionein, phytochelatins, amino acids (malate, citrate, histidine, oxalate, nicotinamine) and phosphate derivatives in the cytosol and transforming them to nontoxic forms (Hall, 2002).

Mixture of biocommunicators/allelochemicals are more active than a single compound (Macias et al., 1998). Allelochemicals can be used to enhance abiotic stress tolerance in crop plants as concentration of allelochemicals is inversely related to the growth promoting effect of crop plants (U1 Subtain et al., 2014). These allelochemicals include phenolics, tannins, flavonoids, terpenoids cinnamic acid, quinines, long chain fatty acids, polyecetylenes, straight-chain alcohols, unsaturated lactones and various types of water-soluble organic acids ( $\mathrm{Li}$ et al., 2010). Triacontanol (TRIA) is a plant growth regulator that has been isolated from chloroform-soluble extraction of alfalfa. TRIA is a constituent of plant waxes that has been shown to increase crop growth and yield both under normal (Ries et al., 1977) and abiotic stresses such as salinity (Shahbaz et al., 2013; Zulfiqar and Shahbaz, 2013; Aziz et al., 2015), acidic mist and cadmium stresses (Muthuchelian et al., 2001, 2003).

Rapid growth of crop species can reduce cost of field activities and enhance market value of field products. Among cheaper strategies mulching with alfalfa hay, watering plants with crude extract and foliar application of aqueous extract is very effective to mitigate environmental stresses (Kibatu, 2012). However, optimum method, time and rate of application to crops is necessary for positive results (Ries et al., 1977). It has been reported that alfalfa possesses both stimulatory and inhibitory effects. For example, aqueous extract $(1 \%)$ of alfalfa residues increase germination percentage, lengths of plumule and radical and nutrients uptake in maize (Zea mays L.), while at higher concentration (8\%) decreased seedling biomass (Ahmad et al., 2014).

Soil cadmium at $0-24 \mathrm{mg} \mathrm{kg}^{-1}$ concentration has been found to reduce dry weight of shoot and root, chlorophyll contents and photosynthesis in mustard and pakchoi (Chen et al., 2011). Cadmium at $0,5,20,50$ and $80 \mathrm{mg} \mathrm{L}^{-1}$ levels decreased seedling growth by decreasing shoot and root lengths and germination percentage of four wheat cultivars (Ahmad et al., 2012). Cadmium significantly decreased growth, relative water content (RWC) and chlorophyll contents, while increased hydrogen peroxide $\left(\mathrm{H}_{2} \mathrm{O}_{2}\right)$, malondialdehyde (MDA) and relative membrane permeability in maize seedling (Hussain et al., 2012). In this study, cadmium reduced growth and yield of all wheat varieties, however, alfalfa leaf extract at the rate of $2 \%(\mathrm{v} / \mathrm{v})$ significantly increased growth of all three wheat varieties.

Foliar treatment with alfalfa extract did not alter RWC (\%), chlorophyll contents, total phenolics and total free amino acids, while increased ascorbic acid contents in Punjab-2011 and Millat-2011, total soluble sugars in Millat-2011, free proline contents in all varieties, while decreased total soluble sugars in Galaxy-2013, $\mathrm{H}_{2} \mathrm{O}_{2}, \mathrm{MDA}$ and flavonoid contents in all wheat varieties under stressed or non-stressed conditions. Characterization of alfalfa crude extract has been found to contain phytotoxic compounds such as phenolics (Hall and Henderlong, 1989). Shikur (2015) reported that alfalfa crude aqueous extract spray could not alter growth and yield parameters of lettuce and pepper plant. However root length and yield of beetroot significantly 
changed alfalfa. Furthermore, due to reported phytotoxic effects one time application during early growth stage could be used for weed control and management practices. However, pot experiment is recommended with the objectives to explore time of application and methods for extraction. For, example, in addition to water extracts extraction in some chemicals for better research output for field experiments. Way of extract preparation and application time interval plays both stimulatory and inhibitory effects on different crop species. For, example cold and hot water extract of dried alfalfa leaf (15g) and their dilution (50\%) has been reported different results on yield and yield components of lettuce (Lactuca sativa), beetroot (Beta vulgaris) and pepper (Capsicum annum) with no changes in pepper and lettuce, while significant effect on root length and yield in beetroot.

As it is evident from the current study that foliar application of $2 \%$ alfalfa leaf extract increased leaf ascorbic acid, free proline and total soluble sugars, while decreased RMP (\%) (in Punjab-2011 and Galaxy-2013), flavonoids and $\mathrm{H}_{2} \mathrm{O}_{2}$ contents in all wheat varieties under cadmium stress. It is concluded from the present study that foliar application of $2 \%$ alfalfa leaf extract increased growth and yield of wheat plants that could be attributed to TRIA-induced metabolic changes in the major metabolic pathways in all wheat varieties.

\section{REFERENCES}

[1] Abd Allah, E.F., Hashem, H., Alqarawi, A.A., Alwathnani, H.A. (2015): Alleviation of adverse impact of cadmium stress in sunflower (Helianthus annuus L.) by arbuscular mycorrhizal fungi. - Pakistan Journal of Botany 47(2): 785-795.

[2] Abdo, F.A., Nassar, D.M.A., Gomaa, E.F., Nassar, R.M.A. (2012): Minimizing the harmful effects of cadmium on vegetative growth, leaf anatomy, yield and physiological characteristics of soybean plant [Glycine max (L.) Merrill] by foliar spray with active yeast extract or with garlic cloves extract.- Research Journal of Agriculture and Biological Sciences 8(1): 24-35.

[3] Ahmad, E., Zaidi, A., Khan, M.S., Oves, M. (2012): Heavy metal toxicity to symbiotic nitrogen-fixing microorganism and host legumes.- In: Zaidi, A., Wani, P.A., Khan, M.S. (eds) Toxicity of heavy metals to legumes and bioremediation. Springer, Wien, pp 29-44.

[4] Ahmed, H.A., Salama, M., El-Darier, Marwa, H., El-Dien, Z. (2014): Role of soil moisture in allelopathic activity of Medicago sativa L. residues in Zea mays L. fields.- Journal of Global Biosciences 3(5): 835-847.

[5] Amirjani, M.R. (2012): Effects of cadmium on wheat growth and some physiological factors. - International Journal of Forest, Soil and Erosion 2: 50-58.

[6] Arnon, D.I. (1949): Copper enzymes in isolated chloroplasts, polyphenoxidase in Beta vulgaris. - Plant physiology 24: 1-15.

[7] Asgharipour, M.R., Armin, M. (2010): Inhibitory effects of Sorghum halepens root and leaf extracts on germination and early seedling growth of widely used medicinal plants. - Advances in Environmental Biology 4: 316-324.

[8] Aziz, R., Shahbaz, M., Ashraf, M. (2015): Influence of foliar application of triacontanol on growth attributes, gas exchange and chlorophyll fluorescence in sunflower (Helianthus annuus L.) under saline stress. - Pakistan Journal of Botany 45: 1913-1918.

[9] Bates, L., Waldren, R.P., Teare, I.D. (1973): Rapid determination of free proline for water-stress studies. - Plant and Soil science 39: 205-207. 
[10] Benavides, M.P., Susana, M., Tomaro, M. (2005): Cadmium toxicity in plants. Brazilian Journal of Plant Physiology 17(1): 21-34.

[11] Carmak, I., Horst, J.H. (1991): Effects of aluminum on lipid peroxidation, superoxide dismutase, catalase, and peroxidase activities in root tips of soybean (Glycine max). - Physiologia Plantarum 83: 463-468.

[12] Chance, B., Maehly, A. (1955). Assay of catalase and peroxidase. - Methods in Enzymology 2: 764-817.

[13] Chen, X., Wang, J., Shi, Y., Zhao, M.Q., Chi, G.Y. (2011): Effects of cadmium on growth and photosynthetic activities in pakchoi and mustard. - Botanical Studies 52: 41-46.

[14] Chon, S., Coutts, J.H., Nelson, C.J. (2000): Effect of light, growth media and seedling orientation on bioassays of alfalfa autotoxicity. - Agronomy Journal 92: 715-720.

[15] Darvishi, S.H, Kamajian, M. (2014): 'Effects Cd accumulation abilities of annual alfalfa (Medicago scutellata L.) by humic acid and growth promoting bacteria association'. - Iranian Journal of Plant Physiology 5 (1): 1243 - 1247.

[16] Dhir, B., Sharmila, P., Saradhi, P. (2004): Hydrophytes lack potential to exhibit cadmium stress induced enhancement in lipid peroxidase and proline. - Aquatic Toxicology 66: 141-147.

[17] Elobeid, M., Göbel, C., Feussner, I., Polle, A. (2012): Cadmium interferes with auxin physiology and lignification in poplar. - Journal of Experimental Botany 63: 1413-1421.

[18] Ertani, A., Schiavon, M., Muscolo, A., Nardi, S. (2013): Alfalfa plant-derived biostimulant stimulate short-term growth of salt stressed Zea mays L. plants. - Plant and Soil 364: 145-158.

[19] Ferreira, M.P., Gendron, F., McClure, K.C., Kindscher, K. (2012): North American bioactive plants for human health \& performance. - Global Journal of Research on Medicinal Plants \& Indigenous Medicine 1(11): 568-582.

[20] Hall, J.L. (2002): Cellular mechanisms for heavy metal detoxification and tolerance. - Journal of Experimental Botany 53: 1-11.

[21] Hall, M.H., Henderlong, P.R. (1989): Alfalfa autotoxic fraction characterization and initial separation. - Crop Science 29: 425-428.

[22] Hussain, I., Iqbal, M., Qurat-Ul-Ain, S., Rasheed, R., Mahmood, S., Perveen, A., \& Wahid, A. (2012): Cadmium dose and exposure-time dependent alterations in growth and physiology of maize (Zea mays). - International Journal of Agriculture and Biology 14: 959-964.

[23] Iqbal, M., Ahmad A., Ansari, M.K.A., Qureshi, M.I., Aref, I.M., Khan, P.R., Hegazy, S.S., El-Atta, H., Husen, A., Hakeem, K.R. (2015): - Environmental Reviews 23(1): 44-65.

[24] Jones, M.M., Turner. N.C. (1978): Osmotic adjustment in leaves of sorghum in response to water deficits. - Plant Physiology 61:122-126.

[25] Julkunen-Titto, R. (1985): Phenolic constituents in the leaves of northern willows methods for the analysis of certain phenolics. - Journal of Agriculture and Food Chemistry 33: 213-217.

[26] Khan, Z.I., Ahmad, K., muhammad Ashraf, M., sumaira Yasmeen, S., Ashfaq, A., Sher, M. (2016): Metal accumulation in a potential winter vegetable mustard (Brassica campestris L.) irrigated with different types of waters in Punjab, Pakistan. - Pakistan Journal of Botany 48(2): 535-541.

[27] Kibatu, T. (2012): Alfalfa as growth regulator: the effect of alfalfa (Medicago sativa L.) crude extract on the growth of troyer citrange seedlings. Lab publication, Germen.

[28] Li, Z.H., Wang, Q., Ruan, X., Pan, C.D., Jiang, D.A. (2010): Phenolics and plant allelopathy. - Molecules 15: 8933-8952. 
[29] Macias, F.A., Oliva, R.M., Simonet, A.M., Galindo, J.C.G. (1998): What are allelochemicals? In Allelopathy in rice. Proceedings of the Workshop on Allelopathy in Rice, 25-27 Nov 1996. (ed. M. Olofsdotter), pp. 69-79. IRRI Press, Manilla majus L. fruit waxes. - Chemoecology 12: 107-111.

[30] Mauriès, M. (2003): Luzerne: culture, récolte, conservation, utilization.- France Agricole Editions.

[31] Miller, D.A. (1983): Allelopathic effects of alfalfa. - Journal of Chemical Ecology 9: 1059-1072.

[32] Miller, D.A. (1996): Allelopathy in forage crop systems. - Agronomy Journal 88: 854-859.

[33] Miller, R.W. Al-Khazraji, M.L., Sisson, D.R., Gardiner, D.T. (1995): Alfalfa growth and absorption of cadmium and zinc from soils amended with sewage sludge. Agriculture Ecosystems and Environment 53: 179-184.

[34] Moore, S., Stein, W.H. (1957): A modified ninhydrine method for use in the chromatography of amino acids. - Journal of Biology and Chemistry 176: 367-388.

[35] Mousavi, S.H., Alami-Saeid, KH., Moshatati, A. (2013). Effect of leaf, stem and root extract of alfalfa (Melilotus indicus) on seed germination and seedling growth of wheat (Triticum aestivum). - International Journal of Agriculture and Crop Sciences 5(1): 44-49.

[36] Mukherjee, S.P., Choudhuri, M.A. (1983): Implications of water stress-induced changes in the levels of endogenous ascorbic acid and hydrogen peroxide in Vigna seedlings. - Physiologia Plantarum 58: 166-170.

[37] Muthuchelian, K., Velayutham, M., Nedunchezhian, N. (2003): Ameliorating effect of triacontanol on acidic mistreated Erythrina variegata seedlings changes in growth and photosynthetic activities. - Plant Science 165: 1253-1257.

[38] Muthuchelian, K., Bertamini, M., Nedunchezhian, N. (2001): Triacontanol can protect Erythrina variegata from cadmium toxicity. - Plant Physiology 158: 14871490.

[39] Nardi, S., Pizzeghello, D., Schiavon, M., Ertani, A. (2016): Plant biostimulants: physiological responses induced by protein hydrolyzed-based products and humic substances in plant metabolism. - Scientia Agricola 73(1): 18-23.

[40] Oves, M., Saghir Khan, M., Huda Qari, A., Nadeen Felemban, M., Almeelbi, T. (2016): Heavy Metals: Biological Importance and Detoxification Strategies. Journal of Bioremediation and Biodegradation 7:334 doi: 10.4172/21556199.1000334

[41] Page, V., Feller, U. (2015). Heavy metals in crop plants: transport and redistribution processes on the whole plant level. - Agronomy 5(3): 447-463.

[42] Parmer, P., Kumari, N., Sharma, V. (2013): Structural and functional alterations in photosynthetic apparatus of plants under cadmium stress". - Botanical Studies 54: 45-50.

[43] Perveen, S., Farooq, R., Shahbaz, M. (2016): Thiourea-induced metabolic changes in two mung bean [Vigna radiata (L.) Wilczek] (Fabaceae) varieties under salt stress. - Brazilian Journal of Botany 39(1): 41-54.

[44] Popovic S., Grlju sic S., Cu pic T., Tu cak M., Stjepan ovic M. (2001): Protein and fiber contents in alfalfa leaves and stems. - In : Delgado, I., Lloveras J. (eds.) Quality in lucerne and medics for animal production. Zaragoza-ciheam, pages 215218.

[45] Rady, M.M., Hemida, K.A. (2015): Modulation ofcadmium toxicity and enhancing cadmium-tolerance in wheat seedlings by exogenous application of polyamines. Ecotoxicology and Environmental Safety 119: 178-185.

[46] Randhawa, M.A., Cheema, Z.A., Ali, M.D.A. (2002): Allelopathic effect of sorghum water extract on germination and seedling growth of Trianthema portulacastrum. International Journal of Agriculture and Biology 4: 383-384. 
[47] Rascio, N., Navari-Izzo, F. (2011): Heavy metal hyper accumulating plants: How and why do they do it? And what makes them so interesting? - Plant Science 180: 169-181.

[48] Rice, E.L. (1985): Allelopathy- an overview. pp. 81-105.- In: Cooper-Driver, G. A., Swain, T., Conn, E. E. (eds.) Chemically mediated interactions between plants and other organisms., Springer US, doi: 10.1007/978-1-4757-9658-2_4

[49] Ries, S. (1977): Triacontanol and its second messenger adenosine as plant growth substances. - Plant Physiology 95: 986-989.

[50] Salt, D.E., Blaylock, L.M., Kumar, N.P.B.A., Dushenkov, V., Ensley, D., Chet, I., Raskin, I. (1995): Phytoremediation: a novel strategy for the removal of toxic metals from the environment using plants. - Biotechnology 13: 468-474.

[51] Shahbaz, M., Noreen, N., Perveen, S. (2013): Triacontanol modulates photosynthesis and osmoprotectants in canola (Brassica napus L.) under saline stress. - Journal of Plant Interactions 8(4): 250-259.

[52] Shikur, T.K. (2015): Effect of alfalfa (Medicago sativa) extract on yield and yield components of lettuce (Lactuca sativa), beetroot (Beta vulgaris) and pepper (Capsicum annum). - World Journal of Agricultural Sciences 11 (2): 89-93.

[53] Singh, O.V., Labana, S., Pandey, G., Budhiraja, R., Jain, R.K. (2003): Phytoremediation: an overview of metallic ion decontamination from soil. - Applied Microbiology \& Biotechnology 61: 405-412.

[54] Snedecor, G.W., Cochran, W.G. (1980): Statistical Methods. Seventh Edition.Ames Iowa: The Iowa State University Press.

[55] Sun, S., Li, M., Zuo, J., Jiang, W., Liu, D. (2015): Cadmium effects on mineral accumulation, antioxidant defense system and gas exchange in cucumber. Zemdirbyste-Agriculture 102(2): 193-200.

[56] Sunitha, M.S., Prashant, S., Kumar, S.A., Rao, S., Narasu, M.L., Kavi kishor, P.B. (2012): Cellular and molecular mechanisms of heavy metal tolerance in plants: a brief overview of transgenic plants over-expressing phytochelatin synthase and metallothionein genes. - Plant Cell Biotechnology and Molecular Biology (3\&4): 99-104.

[57] Ul Subtain, M., Hussain, M., Tabassam, M.A.R., Ali, M.A., Ali, M., Mohsin, M., Mubushar, M. (2014): Role of allelopathy $n$ the growth promotion of plants. Scientia Agriculture 6 (3): 141-145.

[58] Velikova, V., Yordanov, I., Edreva, A., (2000): Oxidative stress and some antioxidant system in acid rain treated bean plants: Protective role of exogenous polyamines. - Plant Science 151: 59-66.

[59] Zhi-xin, N., Li-na, S., Tie-heng, S., Yu-shuang, L., Hong, W. (2007): Evaluation of phytoextracting cadmium and lead by sunflower, ricinus, alfalfa and mustard in hydroponic culture. - Journal of Environmental Sciences 19: 961-967.

[60] Zulfiqar, S., Shahbaz, M. (2013). Modulation of gas exchange parameters and photosystem-II activity of canola (Brassica napus L.) by foliar-applied triacontanol under salt stress. - Agrochimica 57(3): 193-200. 